\title{
CONSERVATION OF RECREATIONAL AREA
}

\section{What the Association for the Preservation of Clear lake has ACCOMPLISHed}

\section{By Remley J. Glass}

In the late thirties and the early forties, the need for the protection of recreational, hunting and fishing facilities in northern Iowa lakes and streams had become apparent to sportsmen and property owners in the vicinity of Clear Lake, as well as to residents and citizens of the state as a whole.

Artificial lakes were being created in many localities over the state. Game preserves were set up, state parks established, and arrangements made for fish and game breeding to restock the depleted streams and lakes and upland meadows of Iowa. In the years before the activities of the Association for the Preservation of Clear Lake commenced, many enterprises for its benefit had been developed.

A state park of more than seventy acres had been located on the southeastern shore of Clear Lake in 1924 and 1925. Under the direction of the State Conservation Commission, a fine shelter house had been built of native wood and limestone, docks and bathing beaches prepared and the grounds themselves made ready for the influx of visitors which summer seasons brought to Clear Lake. In pre-war seasons, the annual park attendance was more than one hundred forty thousand and it seems probable that a greater number will utilize the increased park facilities in 1946.

During the passing years many property owners seemed to have forgotten just where their lot lines were located and had encroached upon the public streets, thereby cutting off access to the banks of the lake. To meet this situation, the Clear Lake city council had placed 
rustic signs along the cottage covered shores of Clear Lake indicating where streets and alleys gave the public access to the lake.

However, it seemed to a group of representative citizens in north central Iowa that the "powers that be" in their efforts to establish new recreational centers had failed to recognize and preserve the potentialities of existing facilities, particularly those of Clear Lake. As a result of this feeling, a group of the leaders in cities and towns of that section first met at Mason City in December of 1940 to consider appropriate steps to preserve and protect Clear Lake, so that it might remain a benefit to this generation and those to come as it had been since James Dickirson and Joseph Hewitt built the first cabins on its shores in 1851.

\section{INITIAL ORGANIZATION EFFECTED}

After a number of meetings and much discussion, an organization was effected as all recognized the importance of the undertaking. For the years of 1941 and 1942, the officers of the Association selected were:

Dr. G. A. Bemis, Garner, president

E. H. Wagner, Mason City, vice president

Emil C. Tobsing, Mason City, secretary-treasurer.

while the first Board of Directors were:

C. E. Barnes, of Garner

Theodore Wolfram, of Ventura

Ira W. Jones, of Clear Lake

Dr. H. C. Krueger, of Clear Lake

M. F. Zack, of Mason City

Leo Berry, of Mason City

H. B. Farrer, of Mason City

An aggressive membership drive resulted in securing a representative group of members, and the nominal dues collected enabled the association to begin its activities.

Those first gatherings resulted in the incorporation of "The Association for the Preservation of Clear Lake" whose articles were filed on February 4, 1943. 
In the summer of 1939 while Governor George Wilson was making Clear Lake Iowa's summer capital, the first Governor's Day celebration was held at Clear Lake, with parades on land and water, fireworks and a truly American summer celebration. Politicians met at the summer capital to settle the affairs of state and nation and to determine who would have the best chance for election in the fall. Political log-rolling had an equal place with aquaplaning and political fence-building with fishing and boating. In the succeeding years governors of Iowa have found Clear Lake to be especially adapted as a seat of summer government and Governor's Day became an increasingly important event in each summer season.

With the successful organization of the "Association for the Preservation of Clear Lake," its officers and committeemen took over the entertainment of governors, past, present, and future, not to mention members of the Conservation Commission, U. S. senators and representatives, state officials and members of the General Assembly. These three-day celebrations bring hundreds of visitors from all Iowa to Clear Lake to meet old friends and make new ones, to enjoy the recreational advantages of one of Iowa's finest summer resorts and to experience that hospitality for which north Iowa is noted.

The work of the "Association for the Preservation of Clear Lake" has not been entertaining governors and senators alone, but also has consisted of the arrangement for ponds for pike fingerlings in the nearby countryside, the protection of spawning grounds for all sorts of game fish, the procuring of public shooting grounds, and manifold other enterprises for the betterment of Clear Lake as a Sportsman's Paradise easily reached from all Iowa's cities and towns.

One of the groups which has contributed much to the effectiveness of this organization is the North Central Iowa Rod and Gun Club. Acting with them, the association was able to convince the Conservation Commission 
of the desirability of constructing and maintaining in this area a rearing pond for the development of young pike. A forty-acre tract of land north of the city of Clear Lake met the requirements of such a purpose and had been purchased by the state. The rearing pond was constructed and in successful use until the shortages of materials and manpower during the war years stopped this activity.

Perhaps no one member of the association has done more for this particular project than that enthusiastic and successful fisherman, Frank C. Goodman of Mason City, though all the committeemen did their part. The name of Mr. Goodman is seldom mentioned without recalling the story told of him by a companion on northern fishing trips. Some of the group felt that sitting around a poker table for games of chance and other purposes were important elements of the vacation period, but Frank disagreed and in commenting on the situation, his friend observed, "Why, that so and so comes up here to fish !" No meeting of the association is complete without his friendly presence and words of advice and counsel.

\section{Reliable Map of ARea Available}

An activity incidental to the association's membership drives has been the furnishing to each member a map of Clear Lake, carefully prepared under the direction of R. E. Robertson, Cerro Gordo county engineer in 1943. This map shows depths, channels, bars, reefs, and mossbeds, and indicates where the hopeful fisherman may expect to get various types of fish. Unfortunately, no guaranty of fishing success accompanied the map. A biological survey of Clear Lake was commenced by the State Conservation Commission in 1941 at the suggestion of the association but World War II prevented its completion.

The need for additional recreational areas and game and fishing preserves in and around Clear Lake were soon apparent to the citizens of north Iowa, and of course 
to the members of the Association for the Preservation of Clear Lake. This condition was brought to the attention of this State Conservation Commission, the Executive Council of Iowa and the state legislature. A committee composed of Charles E. Strickland, C. A. Knutson, and $H$. J. Bryant was appointed from the association membership to investigate possible sites, their availability, suitability, and the cost. It soon appeared that a sixty-acre tract of land belonging to the Gilbert B. McIntosh Estate and located on the north shore of Clear Lake, most nearly met the requirements. Negotiations were then undertaken for the acquisition of the land between Mrs. Rose M. McIntosh and her children on the one hand and the State of Iowa on the other with the committee as intermediary. The McIntoshes were one of the pioneer families of Clear Lake and cooperated in the utmost fairness with the state so that the land was purchased in July of 1943 for the reasonable sum of $\$ 30,000.00$.

Under the name of "McIntosh Woods," it became the second state park on the shores of Clear Lake. This beautiful wooded point of land partially separating the main body from the head of the lake was ideally suited - to its purpose. For years, hunters had built their blinds on the sandbar to the south when the duck migrations took place, spawning areas for game fish bordered its shores and picnickers used its oak groves for their gatherings. Roads and paths have been constructed and today it is another natural beauty spot preserved for the people of Iowa through the generous cooperation of the McIntosh family with the Association for the Preservation of Clear Lake.

The dedication of "McIntosh Woods," Iowa's seventysixth state park took place on August 12, 1944, during the sixth Annual Governor's Day celebration at Clear Lake. Dr. H. C. Krueger, president of the association, presided over the 2000 visitors at the ceremonies held on a wooded knoll overlooking Clear Lake to the east, 
west and south. Fred J. Poyneer, chairman of the State Conservation Commission, made the formal presentation of the park to the State of Iowa and all Iowans, while Governor Bourke B. Hickenlooper accepted it on their behalf. Bands from nearby cities and towns were present while a group of WAVES from the Naval Training School at Cedar Falls added a truly nautical touch to the festivities.

Because of an economic situation well known to all of us, further development of the "McIntosh Woods" state park has been materially delayed, but the members of the Conservation Commission assure us that it is not forgotten. They promise that ere long that tract so ideally situated will be one of the finest of Iowa's state parks.

\section{Ventura Marsh A Shooting Reserve}

Another project for which the association presented a united and successful front was the acquisition of a considerable area around the head of the lake near Ventura to protect spawning areas along the shores of that marshy region, and also to create a public shooting reserve. These efforts began in 1940 and terminated in the purchase of 753 acres during the years 1941-1943 through the provisions of the Pittman-Robertson bill. Since that time, the committee in charge of that particular project have been very effective watch dogs preventing any activity which might impair the use of the tract for the intended purposes.

While not directly sponsored by the association, many of its members and their families are actively interested in the yacht races held on Saturday and Sunday during the summer season, when fleets of small craft skippered and manned-or girled-sail around the various courses laid out by the Clear Lake Yacht Club to win the trophies offered by former commodores and interested members. Before the war curtailed gasoline and tires, groups of youthful sailors brought their boats from Okoboji and 
Spirit Lake and from Minnesota lakes as well to contest with the nautical experts of Clear Lake in pretentious regattas. No one can appreciate the beauty of Clear Lake who has not seen the white sailed "X's" or "C's" well heeled over in a spanking breeze winging their way over the blue water against a distant background of cottages peeping through the green foliage along the shores. If you want to see American youth at its best and happiest, you should be present at the annual dinner given by the Club when the trophies are awarded.

In the judgment of its members and according to statements of the state officials, this association is unique in bringing together men from many communities near to Clear Lake and uniting the diverse elements of Conservation Commission, cottagers, fishermen, hunters, and those more particularly interested operators of motor boats for pleasure and profit and a fleet of sail boats in the commercial side of resort activity.

We do our fighting among ourselves-and do not think that meetings of the association are always peace and joy-but after a decision has been reached, the entire group carries on to the determined goal regardless of former internecine strife.

The difference of opinion as to the preservation of reed beds along portions of the lake shore, advantageous as spawning grounds and deemed desirable by fishing enthusiasts, but disadvantageous to cottage owners, is one of the unsettled problems which comes before the association at almost every meeting. Considerable effort has been made to remove enough of water vegetation to prevent interference with navigation while leaving sufficient amount for fish food and this likewise is a matter of never-ending argument.

\section{All Year Activity Maintained}

Twice a year, once at Clear Lake in the spring and once at Mason City in the fall or winter, the officers and committeemen gather for a dinner and business 
meeting to discuss things accomplished and things to be done for the benefit of Clear Lake. After an old-fashioned meal which puts everyone in good humor, reports from the committees are received and discussed pro and con and at last agreement is reached after which the group maintains a united front. Usually experts report on what they are doing for the benefit of recreationists and sportsmen in Iowa with particular reference to our local interests and the meeting adjourns with renewed enthusiasm for Iowa as the greatest agricultural state as well as a sportsman's paradise. These gatherings do much to determine what we want and what we can expect to get for the preservation of Clear Lake during the months and years to come.

During the years since its incorporation, the association has had as its presidents, Dr. G. A. Bemis, E. H. Wagner, Dr. E. H. Krueger, and Charles E. Cornwell, and during the greater part of the time, L. A. Page has served as secretary. These men have directed the policies of the association, but a host of others have given freely of their time and energy in service on committees of all sorts. Dr. G. A. Bemis, its first president, did a mighty fine job as organizer, but no more than Sid Halford in directing annual parties for "Visiting Firemen."

Dr. Krueger's administration brought "McIntosh Woods" into being, but Charlie Strickland, Clarence Knutson, and Harvey Bryant were the committee that negotiated with the owners and the State of Iowa to make possible its purchase.

Charlie Cornwell has been a fine executive, and we also remember how Lawrence Bless and Theo. Wolfram, with the marvelous assistance of their wives and friends, made the entertainment of various governors at the Wolfram home in Ventura overlooking the head of the lake so successful that even now one smiles and gently pats his lower chest in happy memory of those auspicious occasions. 
While Louis Page guarded against raids on the treasury, we cannot forget the efforts of a host of workers who sold memberships to men all over the state and the middle west, making possible the effective work of the organization.

Everyone in this unique association has done his part without hope of dividends, salaries, or bonuses save the good times, experiences and the friendships established and maintained, and the knowledge of worthwhile accomplishments in the cause of conservation.

While at times the important sounding name of this organization, coupled with its many social activities, have been the subjects of jest and banter, still we, who have been its active proponents, feel that its efforts for the preservation of. Clear Lake as one of Iowa's easily accessible beauty spots and recreational centers, have justified its existence and our endeavors.

\section{BOU̇GHT ANOTHER "GOD'S ACRE"}

Iowa land as an endowment was regarded as good in 1855. The Valley Whig related how Bishop Lee was then on a tour of eastern cities to raise money to buy a tract of Iowa land, and "an incident occurred after a lecture of his in Boston which white folks might imitate to advantage. It is related that a poor old colored woman who had listened to the bishop's appeal followed him into the vestry room, after the services were over, and presented him with a dollar and a quarter to buy an acre of ground in Iowa to be devoted to the services of Almighty God." 
Copyright of Annals of Iowa is the property of State of Iowa, by \& through the State Historical Society of Iowa and its content may not be copied or emailed to multiple sites or posted to a listserv without the copyright holder's express written permission. However, users may print, download, or email articles for individual use. 